\title{
PERAN SULTAN SULAIMAN AL-QANUNI DALAM MEMBANGUN KEJAYAAN KESULTANAN TURKI USTMANI PADA ABAD KE-16
}

\author{
Hanifah \\ IAIN Syekh Nurjati Cirebon (nurhanifah505@gmail.com)
}

\begin{abstract}
The writing attempts to describe the reign of the Ottoman Empire in the 16th century, especially during the reign of Sultan Sulayman al-Qanuni. During the reign, he was able to bring glory to the Ottoman Ottoman Empire. One of the ways that is done by making policies (legislation) which is very appropriate and able to change the order of the Ottoman Turkish Sultanate system becomes more controlled and neat administratively. This research uses library research approach with historical study method through four stages, namely data collection (heuristic), verification, interpretation, and writing (historiography). Sultan Sulaiman Al-Qanuni is a leader who has a very strong soul, especially in building the glory of the Ottoman Empire Sultanate. So he was given the title "Solomon The Magnificent" which means "Great Sulaiman Sultan". The more significant policy that Sultan Suleiman Al-Qanuni has made is to regulate legislation that is capable of making the Ottoman Turkish Sultanate system more systematic. The implications of all policies of Sultan Sulaiman Al-Qanuni able to influence in the wider community, even throughout Europe.
\end{abstract}

Keywords: Keywords: Ottoman Turkey, Sulaiman Al-Qanuni, Power, Civilization

\begin{abstract}
Abstrak
Tulisan mencoba menggambarkan tentang pemerintahan Kesultanan Turki Utsmani pada abad ke-16, terutama pada masa Sultan Sulaiman Al-Qanuni. Pada masa pemerintahannya yang mampu membawa kejayaan bagi Kesultanan Turki Utsmaniyah. Adapun salah satu cara yang dilakukannnya yaitu dengan membuat kebijakan-kebijakan (perundang-undang) yang sangat tepat dan mampu merubah tatanan sistem Kesultanan Turki Utsmaniyah menjadi lebih terkontrol dan rapi secara administratif. Penelitian ini menggunakan pendekatan library research dengan metode studi historis yang melalui empat tahapan, yaitu pengumpulan data (heuristik), verifikasi, interpretasi, dan penulisan (historiografi). Sultan Sulaiman Al-Qanuni merupakan sosok pemimpin yang mempunyai jiwa yang sangat tangguh terutama dalam membangun kejayaan Kesultanan Turki Utsmaniyah. Sehingga ia diberi gelar "Solomon The Magnificent" yang berarti "Sultan Sulaiman Yang Luar Biasa". Kebijakan yang lebih signifikan yang telah dibuat Sultan Sulaiman Al-Qanuni yaitu dalam mengatur perundangundangan yang mampu menjadikan tatanan kepemerintahan Kesultanan Turki Utsmaniyah menjadi lebih sistematis. Adapun implikasi dari segala kebijakan Sultan Sulaiman Al-Qanuni mampu mempengaruhi dalam masyarakat luas, bahkan seluruh wilayah Eropa.
\end{abstract}

Kata Kunci: Turki Utsmani, Sulaiman Al-Qanuni, Kekuasaan, Peradaban

\section{A. Pendahuluan}

Sejarah mengatakan bahwasanya Islam pada masa awal sangat maju dan berkembang sangat pesat, disebabkan peranan Kesultanan Islam seperti Dinasti Umayah, Abbasiyah, Saljuk, Fatimiyah dan sebagainya. Paska Islam redup dan tidak mempunyai kekuasaan dan kekuataan, pada masa abad pertengahan muncul kembali kesultanan-kesultanan Islam di dunia yang mampu membangkitkan ghirah semangat Islam dan mencoba kembali membangun puing-puing peradaban yang telah lama lenyap.

Dinasti Turki Utsmani merupakan khalifah yang cukup besar dalam Islam dan memiliki pengaruh cukup signifikan 
dalam perkembangan wilayah Islam di Asia, Afrika dan Eropa. Bangsa Turki memiliki peran yang sangat penting dalam perkembangan peradaban Islam. Peran yang paling menonjol terlihat dalam birokrasi pemerintahan yang bekerja untuk para khilafah Bani Abbasiyah. Kemudian mereka sendiri membangun kekuasaan yang sekalipun independen, tetapi masih tetap mengaku loyal kepada khilafah Bani Abbasiyah. Hal tersebut ditunjukkan dengan munculnya Bani Saljuk. ${ }^{1}$

Dalam sejarah umat Islam, munculnya Kesultanan Turki Utsmaniyah, memiliki peranan yang sangat penting baik dalam pengembangan kebudayaan maupun dalam perluasan wilayah (futuhat) kekusaan Islam. Perluasan wilayah tersebut meliputi tiga benua (Asia, Afrika, dan Eropa) dan dua lautan (Laut Tengah dan Laut Merah). Korelasi dari tertatanya sistem pemerintahan yang teratur dapat dilihat dari hasil pembangunan kebudayaan Kesultanan Turki Utsmani ini dengan nilai arsitektur yang sangat tinggi pada saat itu, bahkan mungkin sampai saat ini. ${ }^{2}$

\footnotetext{
${ }^{1}$ Samsul Munir Amin, Sejarah Peradaban Islam, (Jakarta: Amzah, 2009) Hlm: 193

${ }^{2}$ Samsul Nizar, Sejarah Pendidikan Islam "Menelusuri Jejak Sejarah Pendidikan Era Rasulullah Sampai Indonesia”, (Jakarta: Kencana, 2007) Hlm: 195
}

Terdapat Tiga wilayah yang paling penting di mana orang-orang Muslim berhasil memperluas wilayah Eropa, di antaranya yaitu Andalusia (Spanyol dan Portugal Muslim), Sisilia dan Creta. ${ }^{3}$ Jatuhnya Konstantinopel, yang selama delapan abad tidak berhasil dijatuhkan oleh kaum Muslimin, memberi bukti bahwa kekuatan Kesultanan Turki Ustmaniyah benar-benar tangguh di samping keunggulan mereka dalam taktik strategi serta teknologi perang. Adanya kepemimpinan militer yang jitu dan kekuatan persenjataan yang melebihi semua kekuatan bangsa-bangsa lain pada zamannya ditambah dengan semangat juang yang tinggi dengan mengerahkan segala ilmu dan daya yang ada, semua itulah yang harus dimiliki oleh seluruh ummat. ${ }^{4}$

Dalam sekian lama kekuasaan Kesultanan Turki Utsmaniyah sekitar 625 tahun berkuasa, dan tidak kurang dari tiga puluh delapan sultan. Di antara sekian banyaknya Sultan tersebut, di masa Sultan Sulaiman Al-Qanuni lah puncak perluasan dan kebesaran Turki Utsmani. Ia menguasai Beograd,

3 M. Ali Kettani, Minoritas Muslim, (Jakarta: PT. Raja Grafindo Persada, 2005) Hlm: 31

4 Abu'l Hasan Ali, Islam Membangun Peradaban Dunia, (Jakarta: PT Dunia Pustaka Jaya, 1988) Hlm: 
kepulauan Rodhesia, semenanjung Krym dan ibukotanya, sehingga sampai menerobos Eropa, hingga sampai di Wina ibukota Austria. Orang Barat memberinya dengan gelar "Solomon the Magnificent" atau "Solomon the Great". Putra dari Sultan Salim I ini juga mendapat gelar Al-Qanuni karena memiliki jasa besar dalam menyusun dan mengkaji sistem undang-undang Kesultanan Turki Utsmani. ${ }^{5}$

Pada masa kepemimpinan Sultan Sulaiman inilah kejayaan Kesultanan Turki Utsmaniyah mencapai puncaknya. Ia berhasil memperluas wilayah kekuasaan Turki Utsmaniyah ke beberapa daerah strategis di Benua Eropa, Asia, dan Afrika. ${ }^{6}$ Pada masa pemerintahannya ini sebagian besar wilayah Hongaria, dan Wina serta Rhodes dapat diduduki. ${ }^{7}$

Sejak Turki gagal dalam merebut kota Wina pada tahun $1683 \mathrm{M}$, peranan Kesultanan Ustmaniyah pun di medan peperangan berubah. Sejak tahun 1683 M, tentara Turki kebanyakan hanya berusaha sekedar menangkis pukulan-

\footnotetext{
5 Abdul Syukur Al-Azizi, Kitab Sejarah Peradaban Islam " Menelusuri Jejak-Jejak Peradaban Islam di Barat dan Timur", (Jogjakarta, Saufa, 2014) H lm: 414

${ }^{6}$ Yudi Iswanto, King Sulaiman The Magnificent "Penakluk Hongaria,Serbia Dan Rhodes", (Jakarta: Daras, 2015)

7 Philip K Hitti, History Of Arabs, (Jakarta: Serambi Ilmu Semesta, 2005)
}

pukulan musuh dan tidak berdaya untuk melancarkan serangan-serangan. ${ }^{8}$

Pada masa selanjutnya, wilayah Turki Utsmani yang luas itu sedikit demi sedikit terlepas dari kekuasaannya, direbut oleh negara-negara Eropa yang baru mulai bangkit. Pada tahun 1699 M, terjadi perjanjian Karlowith ${ }^{9}$ yang memaksa sultan untuk menyerahkan seluruh Hongaria, sebagian besar Slovenia dan Kroasia kepada Hasburg dan Heminietz, Pedolia, Ukraina, Morea, dan sebagian Dalmetia kepada orangorang Venesia. Perjanjian Kucuk Kaynarca $1774 \mathrm{M}^{10}$ memperkuat dugaan bahwa militer, teknologi, dan administrasi Eropa lebih unggul dibanding dengan Turki Utsmani. Solusi yang ditempuh oleh para pemimpin kesultanan yaitu dengan mengadopsi kemajuan-kemajuan yang telah dicapai Eropa yang selanjutnya melahirkan gerakan pembaharuan di Turki. ${ }^{11}$

\footnotetext{
${ }^{8}$ Dedi Supriyadi, Sejarah Peradaban Islam, (Bandung: Pustaka Setia, 2008) Hlm: 250

${ }^{9}$ Karlowith merupakan perjanjian damai dengan negara-negara Eropa. Perjanjian ini terjadi pada tahun 1699 M. Dalam perjanjian ini mengatakan bahwa Kesultanan Turki Utsmaniyah harus rela melepaskan wilayah Eropa.

${ }^{10}$ Perjanjian Kucuk Kaynarca (juga dieja Kuchuk Kainarji) atau disebut juga Perjanjian Catharina adalah perjanjian perdamaian yang ditandatangani pada tanggal 21 Juli 1774 antara Kekaisaran Rusia dan Kesultanan Turki Utsmaniyah.

${ }^{11}$ Jaih Mubarok, Sejarah Peradaban Islam, (Bandung, Pustaka Bani Quraisy, 2004) Hlm: 113
} 


\section{B. Biografi Sultan Sulaiman Al-Qanuni (1520-1566 M)}

Sultan Sulaiman Al-Qanuni lahir pada tanggal 6 November 1469 M di Trabzon, sebuah kota yang terletak di Turki bagian Timur Laut di kawasan pantai Laut Hitam. ${ }^{12}$ Nama ibunya adalah Ayse Hafsa Valide Sultan atau sering disingkat Hafsa Sultan. ${ }^{13}$ Sedangkan ayahnya bernama Sultan Selim I. ${ }^{14}$ Awal pemerintahan Sultan Salim I membuat Kesultanan Turki Utsmaniyah semakin maju dan berkembang dengan baik. Di antara usahanya yaitu dengan melakukan penaklukan-penaklukan wilayah bagian Timur, yaitu meliputi Persia, Syiria, dan Mamluk Mesir. Setelah Sultan Salim I meninggal dunia, kepemimpinan

12 Yudi Iswanto, King Sulaiman The Magnificent, (Jakarta: Daras Books, 2015) hlm: 53

${ }^{13}$ Hafsa Sultan menjadi salah satu tokoh yang paling berpengaruh di Kesultanan Turki Utsmaniyah saat putranya naik tahta pada tahun $1520 \mathrm{M}$, karena ia merupakan wali de facto putranya selama empat belas tahun sampai akhirnya ia meninggal pada tahun $1534 \mathrm{M}$.

14 Sultan Salim Han atau yang biasa disebut Sultan Salim I, ia adalah ayah dari Sultan Sulaiman Al-Qanuni, ia memerintah Kesultanan Turki Utsmaniyah dari tahun 1512-1520 M setelah menggantikan Sultan Beyazid II. Sultan Salim I merupakan seorang ahli penyair pada masanya. Ia meninggal pada 9 Syawal 926 H / 22 September 1520 M karena infeksi kulit, akan tetapi beberapa ahli sejarah menyakini penyebab kematiannya karena diracuni oleh tabib yang merawatnya. Lihat Yudi Iswanto, King Sulaiman The Magnificent, (Jakarta: Daras Books, 2015) Hlm: 47
Kesultanan Turki Utsmaniyah digantikan oleh Sultan Sulaiman Al-Qanuni dengan membawa banyak kemajuan bagi Turki Utsmaniyah, bahkan pencapaiannya melebihi apa yang sudah diraih Sultan Salim I dan para sultan pendahulunya.

Sebagian sejarawan mengklaim pada masa remaja Sultan Sulaiman AlQanuni mengagumi Alexsander Agung. ${ }^{15}$ Oleh sebab itulah Sultan Sulaiman Al-Qanuni sangat mengagumi sosok Alexander Agung, karena telah memberikan pengaruh dalam pola pemikirannya untuk membangun kesultanan dengan wilayah yang luas, sehingga dapat memperluas kekuasaannya hingga ke wilayah Asia, Afrika, dan Eropa. ${ }^{16}$

Kehebatan serta kepiawaiannya Sultan Sulaiman dalam berperang dan menaklukan banyak daerah merupakan hasil didikan orang tuanya sejak ia masih kecil. Sejak usia tujuh tahun, Sultan

\footnotetext{
${ }^{15}$ Alexander Agung adalah seorang raja dari Kekaisaran Makedonia, sebuah negara di daerah timur Laut Yunani, yang pada usia tiga puluh tahun memimpin sebuah kekaisaran terbesar pada masa sejarah kuno, membentang mulai dari Laut Lonia sampai pegunungan Himalaya, Alexander Agung tidak pernah terkalahkan dalam pertempuran dan dianggap sebagai komandan perang terhebat sepanjang masa. Lihat Yudi Iswanato, King Sulaiman The Magnificent, (Jakarta: Daras Books, 2015) Hlm: 54

${ }^{16}$ Amriadi Al masjidy, Sultan Sulaiman Al Qanuni Dan Turki Usmani http://amriadicyber.blogspot.co.id/2016/01/sultan -sulaiman-al-qanuni-dan-turki.html, diunduh pada tanggal 20/05/16 pukul 15.45 WIB
} 
Sulaiman sudah mempelajari banyak bidang keilmuan. Ia mengikuti pendidikan di sekolah Topkapi ${ }^{17}$ di Konstantinopel. Sultan Sulaiman AlQanuni merupakan sosok yang sangat berhati-hati dan tidak tergesa-gesa dalam setiap tindakan. Sebelum mengambil tindakan, dia selalu memikirkan resikoresikonya atas segala keputusan yang diambilnya. $^{18}$

Selain seorang reformator yang energik, Sultan Sulaiman Al-Qanuni dikenal sebagai penguasa yang sungguhsungguh adil dan imbang. Ia mengangkat kedudukan para pengabdinya sesuai kemampuan mereka, tidak memandang dari kekayaan pribadi ataupun latar belakang keluarga melainkan dari kemamampuan dan prestasinya. ${ }^{19}$ Bahkan banyak pejabat paling penting Sultan Sulaiman Al-Qanuni berasal dari kaum budak beragama Kristen di

\footnotetext{
${ }^{17}$ Topkapi adalah sebuah Istana di Istanbul, Turki yang merupakan kediaman resmi Sultan Utsmaniyah selama lebih dari 600 tahun 14651856 M. Yang terletak di pinggir pantai selat Basphorus dan berada tidak jauh dari Hagia Sophia. Istana Topkapi ini selain digunakan sebagai tempat tinggal kesultanan, juga digunakan untuk acara-acara penting kesultanan. Pembangunan Istana ini dimulai pada tahun 1459 M atas perintah Sultan Mehmed II. Lihat dalam karya Abdul Syukur Al-Azizi, Kitab Sejarah Peradaban Islam Terlengkap, Hlm: 423

${ }^{18}$ Ali Muhammad Ash-Shalabi, Bangkit Dan Runtuhnya Khilafah Utsmaniyah, (Jakarta: Pustaka Al-Kautsar, 2003) Hlm: 240

${ }^{19}$ Simon Sebag Montefiore, Pahlawan Dalam Sejarah Dunia, Terj: Damaring Tyas Wulandari. (Jakarta: Erlangga, 2012) Hlm: 91
}

Kesultanan Tutki Utsmaniyah ini. Dengan sebab itu membuktikan bahwa kepribadian Sultan Sulaiman Al-Qanuni tidak bisa diragukan lagi dalam memimpin Kesultanan Turki Utsmaniyah, sehingga kemajuankemajuan dapat diraihnya.

\section{Sultan Sulaiman Al-Qanuni} mempunyai dua istri, yaitu istri pertama bernama Mahidevran Gulbahar Sultan yang dikaruniai dua anak dari pernikahannya, yaitu Sehzade Mustafa dan Raziye Sultan. Adapun dari istri kedua Sultan Sulaiman Al-Qanuni menikahi seorang wanita harem ${ }^{20}$ yang bernama Hurrem Sultan. Pernikahan Hurrem Sultan dan Sultan Sulaiman AlQanuni dikaruniai enam anak, yaitu Putri Mihrimah, Selim II, Beyazid, Abdullah, Cihangir, dan Mehmed. Dari keenam anaknya tersebut, Selim II yang nantinya akan menggantikan posisi Sultan Sulaiman sebagai sultan Utsmaniyah. Adapun dalam pernikahannya dengan Mahidevran Gulbahar Sultan, mereka dikaruniai dua orang anak, yaitu Sehzade Mustafa dan Raziye Sultan. Jadi keseluruhan anak dari Sultan Sulaiman Al-Qanuni berjumlah delapan anak dari dua istri.

\footnotetext{
${ }^{20}$ Istilah wanita harem berasal dari kata harim dalam bahasa Arab yang artinya sebuah ruangan khusus wanita di dalam rumah yang menganut sistem rumah tangga poligini.
} 
Sebenarnya antara anak Mahidevran dan Hurrem Sultan juga terjalin hubungan yang sangat baik, bahkan beberapa di antara mereka bersahabat karib dan menjalin persaudaraan yang baik. Namun intrikintrik di wilayah kekuasaan Kesultanan Turki Utsmaniyah membuat mereka ikut terseret dalam permainan politik tingkat tinggi. Misalnya, Jihangir anak dari Hurrem Sultan bersahabat baik dengan Mustafa anak dari Mahidevran.

Kematian Mustafa memang sudah direncakan oleh pihak-pihak tertentu. Pada tahun $1552 \mathrm{M}$ terjadi intrik politik yang menjatuhkan Mustafa, ketika itu ia difitnah oleh Rustam Pasha, yang merupakan suami dari Mihrimah anak dari Hurrem Sultan, dikatakan bahwa Mustafa akan mengambil alih kekuasaan Sultan Sulaiman Al-Qanuni. Akhirnya, Mustafa tewas dibunuh oleh orang-orang kepercayaan Sultan Sulaiman AlQanuni, diduga para kasim kesultanan yang telah membunuh Mustafa. Karena begitu dalamnya kesediahan Jihangir hingga beberapa kemudian ia pun meninggal dunia, karena tidak mampu lagi menahan kesedihan yang begitu dalam atas kematian Mustafa yang sangat mengenaskan karena dibunuh. ${ }^{21}$

\footnotetext{
${ }^{21}$ Ibid, Hlm: 65
}

Di masa mudanya menuntut ilmu, Sultan Sulaiman Al-Qanuni bersahabat dengan seorang pemuda bernama Pergali Ibrahim Pasha atau yang biasa dipanggil Ibrahim, seorang budak yang nanti di kemudian hari menjadi orang kepercayaan sekaligus penasihat pribadinya. $^{22}$ Sultan Sulaiman menjadikan Pargali Ibrahim Pasha sebagai falconer $^{23}$ kesultanan. Setelah menugaskan Pargali Ibrahim Pasha menjadi falconer, kemudian Sultan Sulaiman Al-Qanuni menaikkan jabatan sahabatnya itu menjadi perwira pertama ruang tidur kesultanan. Begitupun jabatan tertinggi yang diberikan Sultan Sulaiman Al-Qanuni terhadap Pargali Ibrahim Pasha adalah saat ia mengangkat Pargali Ibrahim Pasha sebagai Wazir Agung Kesultanan Turki Utsmani pada tahun $1523 \mathrm{M}^{24}$

Sebelum menduduki tahta kesultanan Utsmani, pada usia 17 tahun Sultan Sulaiman Al-Qanuni ditunjuk sang ayah untuk menjadi gubernur pertama Provinsi Kaffa (Theodosia),

\footnotetext{
${ }^{22}$ Ibid, Hlm:71

${ }^{23}$ Falconer kesultanan, yaitu orang yang bertugas untuk menerbangkan burung pemburu, biasanya dari jenis elang atau rajawali. Kegiatan ini merupakan jenis olahraga atau permainan yang dulunya banyak dimainkan oleh kalangan bangsawan atau kesultanan untuk aktivitas berburu. Lihat dalam buku karangan Yudi Iswanto, King Sulaiman The Magnificent, Hlm: 72.
}

${ }^{24}$ Ibid, Hlm: 72 
pada tahun 1511 M. Setelah itu, ia diuji dengan menduduki jabatan Gubernur Sarukhan (Manisa) dan kemudian memimpin masyarakat di Edirne (Adrianople). Delapan hari setelah sang ayah (Sultan Salim I) tutup usia, pada 30 September 1520 M, Sultan Sulaiman AlQanuni naik tahta menjadi sultan ke-10 Kesultanan Turki Usmaniyah, pada usia 25 tahun. Sultan Salim I dikenal sebagai seorang Sultan yang alim dan memiliki sifat utama dan cerdik. Dalam hidupnya ia mempunyai rencana visi dan misi, serta tekad yang keras. ${ }^{25}$

Di awal pemerintahan Sultan Sulaiman Al-Qanuni sudah menghadapi cobaan berat. Ia harus berhadapan dengan empat gerakan pembangkangan sekaligus. Pembangkangan tersebut dilakukan oleh Janbarad, Ahmad Syah, Baba Dzunnun, dan Qalandar Jalabi. Adapun motivasi para pemberontak, mereka mengira kekuatan Kesultanan Turki Utsmani semskin melemah, sehingga mereka berani memerdekakan diri dan menyatakan sebagai wilayah independen. ${ }^{26}$

Bagaimanapun juga, masa pemerintahan Sultan Sulaiman AlQanuni merupakan respresentasi puncak

25 Ali Muhammad Ash-Salabi, Bangkit Dan Runtuhnya Khilafah Utsmaniyah, (Jakarta: Pustaka Al-Kautsar, 2011) Hlm: 239

${ }^{26}$ Ibid, Hlm: 240 kejayaan politik Khilafah Turki Utsmaniyah dan puncak kemuliaan Sultan di tengah pusaran dunia di masa itu. Masa pemerintahan Sultan Sulaiman Al-Qanuni dianggap sebagai puncak zaman keemasan pemerintahan Turki Utsmaniyah.

Masa pemerintahan ini berlangsung dalam kurun 1520-1566 M. Di masa itu wilayah Kesultanan Turki Utsmaniyah meluas sedemikian rupa, melebihi wilayah-wilayah yang dicapai oleh Sultan-sultan sebelumnya. Kekuasaan Kesultanan Turki Utsmaniyah kala itu menjangkau tiga wilayah benua, Asia, Afrika dan Eropa. ${ }^{27}$

\section{Kondisi Kesultanan Turki} Utsmaniyah Sebelum Kepemimpinan Sultan Sulaiman Al-Qanuni

\section{Kondisi Sosial Masyarakat}

Bangsa-bangsa Turki sendiri sejak dulu bahkan hingga kini tetap menjadi kelompok minoritas dalam lingkup kekuasaan mereka yang begitu luas, dan tidak pernah berusaha menjajah negerinegeri Arab. Keluarga penguasa memelihara keturunan mereka dengan cara menikahi wanita-wanita nonmuslim, dan memberikan hak kewarganegaraan yang penuh kepada siapa pun yang menerima Islam,

${ }^{27}$ Ibid, Hlm: 247 
memakai bahasa Turki, dan bekerjasama dengan penguasa. ${ }^{28}$

Sistem rekrutmen pasukan dari kalangan remaja dan pemuda yang selama ini dipertahankan memungkinkan mereka untuk memenuhi kebutuhan militer dan layanan sipil, serta mampu menyaingi pesatnya pertumbuhan anak muda dari komunitas nonmuslim. Anakanak muda yang berbakat dari kelompok masyarakat yang ditaklukan digiring dan disalurkan ke ibukota. Kemudian di sana mereka diislamkan, diturkikan, dan digunakan demi keagungan dan kemajuan negara. Orang-orang Sirkasius, Yunani, Albania, Slavia, Italia, bahkan Armenia berhasil mencapai kedudukan yang tinggi di kesultanan, bahkan ada yang menjadi menteri, atau perdana menteri. ${ }^{29}$

Keseluruhan kebudayaan Turki merupakan campuran dari beraneka ragam elemen yang berbeda-beda. Dari orang Persia, yang telah berhubungan dengan bangsa Turki bahkan sebelum mereka berimigrasi ke Asia Barat, lahir corak-corak yang artistik, pola-pola yang yang indah, serta ide-ide politik yang mengangkat keagungan raja. Dengan mengadopsi karakter-karakter Islam dan Arab, ribuan istilah keagamaan, ilmu

${ }^{28}$ Philip K. Hitti, History Of Arab's, (Jakarta: Serambi Ilmu Semesta, 2005) Hlm: 913

${ }^{29}$ Ibid, Hlm: 914 pengetahuan, hukum, dan sastra dipinjam dari bahasa Arab dan bahasa Persia, dan banyak di antara istilah itu yang masih digunakan di Turki walaupun baru-baru ini ada gerakan nasionalisasi bahasa. Kesultanan Utsmani memberikan kontribusi orisinal yang cukup berarti dalam tiga bidang berikut: ilmu ketatanegaraan, arsitektur, dan puisi.

\section{Kondisi Keagamaan Kesultanan}

\section{Turki Utsmaniyah Sebelum Sultan}

\section{Sulaiman Al-Qanuni}

Dalam tradisi masyarakat Turki, agama merupakan sebuah faktor penting dalam transformasi sosial dan politik seluruh masyarakat. Masyarakat digolongkan berdasarkan agama, dan kesultanan sendiri sangat terikat dengan syariat sehingga fatwa ulama menjadi hukum yang berlaku. ${ }^{30}$ Oleh karena itu, ulama mempunyai kedudukan yang istimewa dalam kesultanan dan berfungsi sebagai penasehat politik sultan.

Pada periode pertama Turki, dipimpin oleh beberapa sultan di antaranya yaitu Utsman I, Orkhan, Murad I, dan Bayazid I. Utsman mendapat gelar Padisya Alu Utsman atau Raja dari keluarga Utsman. Semangat

30 Samsul Munir Amin, Sejarah Peradaban Islam, (Jakarta: Amzah, 2009), Hlm: 204 
pasukan Kesultanan Turki Utsmaniyah didorong oleh jiwa agama Islam yang berbasis pada ajaran Tarekat Bektasyiyyah $^{31}$ yang dipelopori oleh Hajji Bektasy.

\section{Kondisi Ekonomi}

Keadaan

perekonomian

Kesultanan Turki Utsmani pada masa sebelum kepemerintahan Sultan Sulaiman Al-Qanuni mengalami peningkatan yang sama besar dengan kemajuan dalam bidang politik dan militer. Daerah-daerah yang ditaklukan dari segi ekonomi merupakan masukan bagi sumber ekonomi kesultanan. Hal ini dikarenakan dalam setiap keberhasilan kesultanan mendapatkan rampasan perang, jizyah, dan pajak sesudahnya.

Dengan demikian, tidak mengherankan jika Kesultanan Turki Utsmaniyah mendapat kemajuan ekonomi melalui perdagangan. Sebagai contoh kegiatan perdagangan itu adalah adanya kerja sama perdagangan antara Kesultanan Turki Utsmaniyah dan Inggris, Genoa, dan Venesia dalam jual

31 Tarekat Bektashiyah didirikan oleh Hajji Bektash asal Khurasan. Tarekat ini menyebar luas melalui Ottoman terutama ke wilayah Balkan. Dimana para pemimpinnya membantu mengkoversi Islam. Gagasan Syiah masuk dengan kuatnya pada tarekat sufi ini, tarekat ini terbatas di Anatolia, Turki. Tarekat ini memiliki pengaruh yang sangat dominan dikalangan Yenniseri, sehingga sering disebut tentara Bektasyi. beli jagung, kacang-kacangan dan timah pada abad ke-16 M. ${ }^{32}$

Kemajuan dalam bidang ekonomi sama besar dan kuatnya dengan kemajuan dalam bidang politik dan militer. Daerah kekuasaan yang luas memungkinkan Kesultanan Turki Utsmaniyah untuk membangun perekonomiannya yang kuat dan maju. Pada masa puncak kemajuannya, semua daerah dan kota penting yang menjadi pusat perdagangan dan perekonomian jatuh ke tangannya. ${ }^{33}$

\section{Kondisi Politik Dan Militer}

Tentara Utsmani dari segi susunan organisasinya kurang rapih, maka dibentuklah tentara dengan memilih dan melatih tentaranya dengan ketat. Tapi setelah mereka ini dibentuk ternyata mereka lupa akan tugas mereka yang sebenarnya sebagai tentara. Kemudian oleh Orkhan berusaha untuk membentuk tentara dari orang-orang non-Turki.

Penguasa Turki cenderung mengambil orang-orang Kristen yang telah berpengalaman dan telah terbiasa dengan organisasi semacam ini. Atas pertimbangan agama, mereka kemudian mengambil anak orang Nasrani untuk dididik dan diarahkan agar masuk Islam.

\footnotetext{
32 Ading Kusdiana, Sejarah Kebudayaan Islam (Periode Pertengahan), (Bandung: CV Pustaka Setia, 2013) Hlm: 133

${ }^{33}$ Syafiq A. Mughni, Sejarah Kebudayaan Islam di Turki, (Jakarta: Logos, 1997) Hlm: 104
} 
Mereka dilatih dengan keras. Dari mereka inilah terbentuk asal pasukan Jenissari Inkisyariyah ${ }^{34}$

Dalam kepemimpinannya Sultan Salim I merombak segala bentuk perhatian pertahanannya ke arah Timur dengan menaklukkan Syria, Persia dan juga Mamalik di Mesir. Akan tetapi dalam masa pemerintahannya ada sebagian daerah yang belum dikembangkannya. Dan akhirnya usahausahanya itu dikembangkan kembali oleh anaknya yaitu Sultan Sulaiman AlQanuni. Sultan Sulaiman Al-Qanuni tidak menitikberatkan hanya kepada satu arah semata, akan tetapi seluruh wilayah yang berada di sekitar Kesultanan Turki Utsmani telah membuat dirinya bersemangat dan berjuang untuk mendapatkan seluruh wilayah tersebut, khususnya wilayah Eropa.

\section{Peran dan Implikasi Sultan Sulaiman} Al-Qanuni dalam Kesultanan Turki Utsmaniyah

\footnotetext{
34 Jennissari atau Inkisyariah, secara bahasa berarti: "pasukan baru", yang dibentuk melalui Devshirme atau semacam pendidikan wajib militer ketika masa kepemimpinan Orkhan. Adapun Inkisyariyah adalah tentara Kesultanan Turki Utsmaniyah yang berasal dari bangsa Georgia dan Armenia yang baru masuk Islam. Pasukan ini merupakan mesin perang yang sangat kuat dalam Kesultanan Turki Utsmaniyah.
}

\section{Peran Sultan Sulaiman Al-Qanuni dalam sistem perundang- undangan}

Sulaiman al-Qanuni lebih dikenal oleh rakyatnya dengan sebutan yang sangat mulia "al-Qanuni". ${ }^{35} \mathrm{Hal}$ itu karena mereka sangat menghormatinya sehingga namanya diabadikan menjadi nama himpunan perundang-undangan oleh generasi setelahnya. Sultan Sulaiman al-Qanuni meminta Ibrahim alHalabi untuk menyusun sebuah kitab hukum (Qanun) yang oleh Sultan diberi nama Multaqa al-Abhur. ${ }^{36}$

Adapun Hukum utama yang digunakan oleh Sultan Sulaiman dalam

${ }^{35}$ Asal kata "al-Qaanuun" yang berarti pokok, pangkal, asal, kemudian menjadi isim fail "alQanuni" berarti peletak Undang-undang/ penetap Undang-undang/ orang yang menjalankan Undang-undang. Dalam sumber lain juga dijelaskan bahwa, Gelar "al-Qanuni" yang diberikan kepada Sulaiman I adalah karena jasanya dalam menyusun dan mengkaji sebuah sistem undang-undang dari Kesultanan Turki Utsmaniyah. Tak hanya itu, Sulaiman I (alQanuni) juga sangat disiplin, tegas, dan konsisten dalam setiap menjalankan undangundang tersebut. Selain itu, dia juga mempunyai sebuah kharisma yang tinggi sehingga ia sangat dihormati dan disegani oleh kawan maupun lawannya. Disebutkan bahwa, Sulaiman I telah menerapkan Hukum Syariah Islamiyah ketika memimpin rakyatnya yang tersebar luas di antara Eropa, Persia, Afrika, serta Asia Tengah. Tidak hanya menerapkan, tetapi dia juga dengan tegas memerintahkan kepada rakyatnya untuk menjalankan dengan disiplin.

\footnotetext{
${ }^{36}$ Kitab hukum yang berjudul Multaqa al-Abhur yang berarti titik pertemuan lautan, yang kemudian menjadi karya standar menyangkut undang-undang hukum Utsmani hingga terjadinya reformasi pada abad ke 19. Lihat Philip K. Hitti, History Of Arab's. Hlm: 911.
} 
mengatur negara adalah syariat Islam Sultan tidak mempunyai kewenangan atau hak apapun untuk mengubah syariat Islam terebut. Dengan bantuan Mufti Agung Kesultanan Turki Utsmaniyah saat itu, Abu Su'ud, ${ }^{37}$ Sultan Sulaiman Al-Qanuni melakukan upaya reformasi undang-undang yang disesuaikan dengan perubahan zaman dan kondisi kesultanan. ${ }^{38}$

Dalam setiap undang-undang yang dibuat oleh Sultan Sulaiman Al-Qanuni mampu memberikan keadilan terhadap umat lain, sehingga seluruh penduduk Kristen maupun Yahudi merasa mendapatkan keadilan atas apa yang menjadi keputusan undang-undang tersebut. Dalam hal ini Sultan Sulaiman Al-Qanuni sangatlah berhati-hati dalam mengambil keputusan.

Pada tahun 1554 M, Sultan Sulaiman Al-Qanuni mengeluarkan dekrit yang isinya secara resmi melarang blood libel $^{39}$ terhadap orang Yahudi.

${ }^{37}$ Syaikh Abu Su'ud Affandi ialah seorang ulama ahli bahasa, ahli tafsir, peneliti, penulis kitab Tafsir Irsyad al-Aql as-Salim ila Mazaya alKitab al-Karim, atau yang sering dikenal dengan tafsir Abu Su'ud. Tafsir ini tebalnya 9 jilid, banyak menjelaskan sisi keistimewaan bahasa dan logika yang diajarkan Al-Quran.

${ }^{38}$ Yudi Iswanto, King Sulaiman The Magnificent,( Jakarta: Daras Books, 2015) Hlm: 135

${ }^{39}$ Blood Libel adalah tuduhan yang disangkakan kepada orang-orang Yahudi atas praktik pemujaan dalam ritual keagamaan mereka yang dilakukan dengan cara meminum darah orang
Bahkan Sultan Sulaiman Al-Qanuni juga melakukan terobosan hukum yang sangat baik dalam bidang undangundang kriminal dan kepolisian, perpajakan, serta pertanahan. ${ }^{40}$

\section{Upaya Sultan Sulaiman Al-Qanuni} dalam Membangun Pasukan yang Kuat

Upaya pertama yang dilakukan Sultan Sulaiman Al-Qanuni dalam membentuk suatu pasukan yang kuat yaitu dengan sistem rekrutmen pasukan dari kalangan remaja dan pemuda. Dengan sistem rekrutmen tersebut, para pemuda yang telah dipilih dan dianggap berbakat dari kelompok masyarakat digiring dan disalurkan ke ibukota. Kemudian mereka tidak hanya diislamkan dan diturkikan. Melainkan mereka juga diberikan pendidikan formal maupun pendidikan militer. ${ }^{41}$

Dalam menghadapi gempuran Eropa yang jumlah lebih banyak, Sulaiman Al-Qanuni membagi pasukannya menjadi tiga barisan sepanjang $10 \mathrm{Km}$. Jenissari diletakkan di garis depan guna menghadapi gempuran langsung pihak musuh. Baris kedua diisi

yang dikorbankan. Lihat Yudi Iswanto, King Sulaiman, Hlm: 140

40 Yudi Iswanto, King Sulaiman The Magnificent,( Jakarta: Daras Books, 2015) Hlm: 140

${ }^{41}$ Philip K. Hitti, History Of Arab's. (Jakarta: PT. Serambi Ilmu Semesta, 2005) Hlm: 914 
oleh kavaleri dan infanteri (pasukan pejalan kaki) yang dilengkapi dengan persenjataan ringan. Sedangkan baris ketiga adalah beliau dengan pasukan meriam.

Dalam buku karangan Philip K. Hitti dikatakan bahwa, Khairuddin Barbarosa mendirikan aristokrasi militer dengan psukan Jenisseri sebagai kekuatannya. Ia juga mengorganisir satu pasukan khusus yang anggotanya diatur secara reguler. Pasukan-pasukan tersebut kebanyakan dari hasil pengrekrutan dari orang Kristen yang berhianat yang mayoritas dari masyarakat Italia dan Yunani. Mereka senantisa siap untuk melaksanakan kebijakan-kebijakan kekaisaran yang agresif ke seluruh kawasan Mediterenia. ${ }^{42}$

\section{Kebijakan Dalam Bidang Militer}

\section{a. Penaklukan Di Eropa}

Pada masa pemerintahan Sultan Sulaiman Al-Qanuni mencapai puncak perluasan dan kebesarannya. Ia menguasai Beograd ${ }^{43}$, kepulauan Rodhesia, semenanjung Krym dan ibukotanya Valachie, dan menerobos Eropa, hingga sampai di Wina

${ }^{42}$ Ibid, Hlm: 906

${ }^{43}$ Beograde atau Beograd adalah ibukota Serbia dan merupakan kota terbesar di Serbia sejak tahun 2006, kemudian Serbia dan Montenegro tahun 2003-2006 dan Yugoslavia tahun 19182003. Kota ini mempunya luas wilayah 3600 $\mathrm{km} 2$. ibukota dari Austria. Dia melakukan pengepungan dua kali, menaklukan Hungaria, dan menumpas habis orang-orang Portugis di pesisir India, dan juga mengalahkannya pada tahun 1537 M. Dia menunduhkan sebagian besar wilayah negeri-negeri Arab. ${ }^{44}$

Target penaklukan utama di wilayah Eropa adalah Beograd. Sultan Sulaiman Al-Qanuni merebut Kota Serbia dari Kesultanan Hongaria. $^{45}$ Penaklukan yang dilakukan oleh pasukan Sultan Sulaiman terhadap Hongaria sebagai salah satu pertahanan terkuat umat Kristen menyebabkan ketakutan dan kekhawatiran di seluruh kawasan Eropa.

Kemenangan yang diraih Kesultanan Turki Utsmaniyah atas Hongaria ini menimbulkan kemunduran bagi Hongaria dan sebaliknya Kesultanan Turki Utsmaniyah menjelma menjadi kekuatan utama di kawasan Eropa Timur. $^{46}$

Wilayah Buda yang sudah
berhasil dikuasai oleh

\footnotetext{
44 Ahmad al-Usairy, Sejarah Islam, (Jakarta: Akbar Media Eka Sarana, 2003) hlm: 364

45 Simon Sebag Montefiore, Pahlawan Dalam Sejarah Dunia, Terj: Damaring Tyas Wulandari. (Jakarta: Erlangga, 2012) Hlm: 90

${ }^{46}$ Yudi Iswanto, King Sulaiman The Magnificent, (Jakarta: Daras Books, 2015) Hlm: 95
} 
Sulaiman Al-Qanuni diserang oleh pasukan Habsburg yang dipimpin oleh Karl $\mathrm{V}^{47}$ dan Ferdinand $\mathrm{I}^{48}$ Serangan tersebut berhasil menaklukan Buda dan mengambil alih Hongaria dari penguasa Kesultanan Turki Utsmaniyah. Kemudian beberapa saat itu juga Sultan Sulaiman Al-Qanuni pun kembali mengerahkan seluruh pasukan Kesultanan Utsmaniyah pada tahun $1529 \mathrm{M}$, untuk merebut kembali wilayah Buda. Dengan penyerangan hebat yang dilakukan Sultan Sulaiman Al-Qanuni.

\section{b. Perang Utsmaniyah dan Safawiyah}

Dinasti Safawiyah merupakan salah satu dinasti yang memegang peranan penting dalam sejarah negara Iran. Dinasti ini menjadi salah satu negeri Persia terbesar sejak terjadinya peristiwa penaklukan Muslim di wilayah Persia pada 644 M. Dinasti ini menjadikan Islam Syiah sebagai agama resmi di Persia dan berkuasa dari tahun 1501- 1722

47 Karl V ialah Kaisar Romawi yang juga merupakan Raja Spanyol, Naples, Sisilia, dan wilayah Burgundi. Di Spanyol Karl V mendapat nama resmi Carlos I, dan terkadang orang Spanyol menjulukinya sebagai El Dorado.

${ }^{48}$ Ferdinand I merupakan Kaisar Romawi yang berkuasa sejak tahun $1558 \mathrm{M}$, Ia menjadi raja Bohemia dan Hongaria pada tahun $1526 \mathrm{M}$, kemudian menjadi raja Kroasia dari tahun 1527 M hingga kematiannya pada tahun $1564 \mathrm{M}$.
M. Adapun wilayah kekuasaan Dinasti Safawiyah cukup luas, yaitu meliputi wilayah Iran, Azerbaijan, Armenia, Irak, Georgia, Afghanistan, Kaukasus, Pakistan, Turkmenistan, dan juga Turki. $^{49}$ Perang Utsmaniyah-Safawiyah ini dipicu oleh persengketaan wilayah antara dua kesultanan, terutama ketika Bey dan Bitlis memutuskan dirinya untuk di bawah perlindungan Persia. ${ }^{50}$

Adapun alasan Sultan Sulaiman Al-Qanuni ingin menaklukan Dinasti Safawiyah. Pertama, karena Gubernur Baghdad yang setia kepada Sultan Sulaiman Al-Qanuni dibunuh oleh Shah Tahmasp ${ }^{51}$, penguasa Dinasti Safawiyah dan kemudian posisi sang gubernur digantikan oleh orang-orang yang setia terhadap Tahmasp. Kedua, Gubernur Bitlis berkhianat kepada Sultan Sulaiman Al-Qanuni dan telah berpihak kepada Dinasti Safawiyah. Kedua alasan tersebut yang membuat keinginan Sultan Sulaiman Al-Qanuni semakin

\footnotetext{
${ }^{49}$ Ibid, Hlm: 102

${ }^{50}$ http://id.m.wikipedia,org/wiki/Perang_Utsmani yah-Safawiyah. Di Unduh pada tanggal 30/06/16 Pukul 12.15 WIB

51 Tahmasp, ialah Shah Iran dari Dinasti Safawiyah yang menjadi penguasa Safawiyah dengan masa kekuasaan paling lama, ia merupakan putra dari Ismail I dan Shah Begi Khanum yang dikenal dengan nama Tajlu Khanum, dari suku Mawsillu Turcoman. Ia naik takhta saat masih berumur 10 tahun pada tahun
} 1524 . 
kuat untuk melakukan perang terhadap Dinasti Safawiyah.

\section{c. Penaklukan di Samudra India dan Hindia}

Setelah berhasil menaklukan beberapa wilayah, akhirnya melanjutkan penaklukan wilayah di Samudra India dan Hindia. Dalam penaklukan kali ini Kesultanan Turki Utsmaniyah sengaja melakukan kesepakatan dengan dua penguasa India, Qaliqut dan Kambay, karena keduanya sangat dirugikan oleh serangan Portugis. ${ }^{52}$

Pada tahun yang sama $1538 \mathrm{M}$, armada dari Kesultanan Turki Utsmaniyah melakukan pengepungan terhadap wilayah Diu India. ${ }^{53}$ Kesultanan Turki Utsmaniyah merasa perlu merebut kota Diu karena sejak dikuasai oleh Portugis berdampak kepada perekonomian yang tidak stabil, pasokan rempahrempah dari kota Diu ke wilayah Mesir menjadi terhambat setelah dikuasai oleh Portugis.

${ }^{52}$ Ali Muhammad Ash-Salabi, Bangkit Dan Runtuhnya Khilafah Utsmaniyah, (Jakarta: Pustaka Al-Kautsar, 2011) Hlm: 240

${ }_{53}$ Diu merupakan kota yang terletak di ujung timur Pulau Diu India, dan dikenal akan benteng dan katedral Portugis. Pada sekitar abad 15 M di kota ini berlangsung pertempuran antara Portugis dan Kesultanan Turki Utsmaniyah, Mesir, dan juga Venesia.
Pada abad ke 16 M, Aceh meningkatkan kemampuan pertahanannya dengan bantuan Kesultanan Turki Utsmaniyah dan Gujarat. Penggunaan artileri dari Kesultanan Turki Utsmaniyah dan juga keterlibatan langsung pasukan dan para penasehat militernya dalam setiap ekspedisi militer yang dilakukan Aceh menunjukan telah terbangun kerjasama yang erat dalam bidang militer antara dua kekuatan dunia Islam ini. Sehingga dalam aspek taktik dan strategi militer Aceh sangat dipengaruhi oleh Kesultanan Turki Utsmaniyah. ${ }^{54}$ Adapun bantuan militer yang diberikan Kesultanan Turki Utsmaniyah kepada Kesultanan Aceh berupa 300 orang prajurit pasukan yang Kesultanan Turki Utsmaniyah. Selain itu juga beberapa orang dari Abesinia dan Gujarat, serta 200 orang saudagar Malabar untuk menaklukkan Tano Batak pada tahun 1539 M. ${ }^{55}$

Dengan demikian hubungan antara Kesultanan Turki Utsmaniyah dan Kesultanan Aceh menjadi erat dengan segala bantuan yang

54 Amirul Hadi, Aceh, Sejarah, Budaya, dan Tradisi, (Jakarta: Yayasan Pustaka Obor Indonesia, 2010) Hlm: 23

55 Yudi Iswanto, King Sulaiman The Magnificent,( Jakarta: Daras Books, 2015) Hlm: 115 
diberikan Kesultanan Turki

Utsmaniyah kepada Aceh. Hal inilah yang menyebabkan Penyebaran Agama Islam semakin muncul di permukaan tidak hanya di Eropa, bahkan sampai ke Nusantara.

4. Implikasi dari kebijakan yang dibuat Sultan Sulaiman Al-Qanuni a. Implikasi Dalam Bidang Politik Peristiwa yang paling monumental dalam kebijakan politik luar negeri pemerintahan Kesultanan Turki Utsmaniyah di masa Sultan Sulaiman Al-Qanuni adalah disaat keberhasilannya menjalin hubungan dengan Francis, Raja Prancis, yang kemudian dijadikan sebagai aliansi politik. Car;les V yang menjadi penguasa Imperium Romawi bersaing dengan Francis I, Raja Perancis untuk menduduki singgasana kekaisaran Romawi, sedangkan Paus Leo $\mathrm{X}$ bersaing dengan Martin Luther tokoh Protestan yang berasal dari Jerman. ${ }^{56}$

Gerakan Protestanisme yang dipelopori oleh Martin Luther terjadi pada 19 April 1529 M di Jerman. Gerakan ini telah diikuti dengan Reformasi di Jenewa yang dirintis Jhon Calvin. Dalam hal ini telah

56 Ali Muhammad Ash-Salabi, Bangkit Dan Runtuhnya Khilafah Utsmaniyah, (Jakarta: Pustaka Al-Kautsar, 2011) Hlm: 244 melahirkan aliran Calvinisme yang semula merupakan gerakan Reformasi Agama. Namun, berikutnya berubah menjadi Reformasi Politik. Gerakan Nasionalisme Protestan berjuang membebaskan Eropa dari penjajahan Katolik. $^{57}$

\section{b. Implikasi Dalam Bidang Pendidikan Masyarakat Turki Utsmaniyah}

Sangat terlihat titik kemajuan ketika masa pemerintahan Sultan Sulaiman Al-Qanuni. Dengan demikian, tidak menutup kemungkinan atas pencapaian yang telah diraih ketika masa pemerintahan Sultan Sulaiman AlQanuni. Dengan mendirikan banyak gedung-gedung madrasah, perpustakaan, masjid, dan berbagai sarana penunjang pendidikan lainnya. ${ }^{58}$

Dampak positif atas kebijakan yang dilakukan oleh Sultan Sulaiman Al-Qanuni dalam bidang pendidikan yaitu, masyarakat dapat merasakan pendidikan dengan jenjang-jenjang pendidikan yang ada. Ada banyak

57 Ahmad Mansur Suryanegara, Api Sejarah 2,(Bandung: PT Grafindo Media Pratama, 2012) Hlm: 141

58 Yudi Iswanto, King Sulaiman The Magnificent, (Jakarta: Daras Books, 2015) Hlm: 145 
terobosan baru yang dilakukan oleh Sultan Sulaiman Al-Qanuni dalam bidang pendidikan di antaranya menggabungkan antara masjid dan sekolah yang dibiayai oleh yayasanyayasan tersebut, anak-anak Muslim yang ingin bersekolah bisa mendapatkan pendidikan secara gratis. $^{59}$

\section{c. Implikasi Dalam Bidang}

\section{Ekonomi}

Keberhasilan Sultan Sulaiman Al-Qanuni berdampak kepada kemakmuran perekonomian Kesultanan Turki Utsmaniyah. Setelah mengambil alih jalur perdagangan India yang dulu dikuasai oleh Portugis. ${ }^{60}$ Atas dasar tersebut akhirnya Sultan Sulaiman Al-Qanuni dapat leluasa mengendalikan perdagangan di kawasan tersebut dan selama abad ke 16 M, Sultan Sulaiman Al-Qanuni berhasil menjaga kegiatan perdagangan dengan India.

Setelah mencapai titik puncak pemerintahan Sultan Sulaiman AlQanuni. Kesultanan Turki Utsmani mulai bergerak turun dan melemah menuju detik kehancuran. Dalam

\footnotetext{
${ }^{59}$ Ibid, Hlm: 146

${ }^{60}$ Ibid, Hlm: 112
}

masa yang panjang itu terjadi karena berbagai pergulatan antara kekuatan penguasa Kesultanan Turki Utsmani dan berbagai sekutu, baik dari dari maupun dari luar Kesultanan Turki Utsmaniyah. Hal ini yang menyebabkan kemuduran terjadi setelah masa pemerintahan Sultan Sulaiman Al-Qanuni. ${ }^{61}$

\section{E. Penutup}

Sultan Sulaiman Al-Qanuni merupakan sosok pemimpin yang mempunyai jiwa yang sangat tangguh terutama dalam membangun kejayaan Kesultanan Turki Utsmaniyah. Sehingga ia diberi gelar "Solomon The Magnificent" yang berarti "Sultan Sulaiman Yang Luar Biasa”. Ia dikenal sebagai penguasa yang tegas dan berwibawa, baik dalam pandangan orang Islam maupun orang Eropa. Sultan Sulaiman Al-Qanuni wafat pada tanggal 05 September $1566 \mathrm{M}$.

Adapun kebijakan Sultan Sulaiman Al-Qanuni dalam upaya membangun Kesultanan Turki Utsmaniyah sangatlah besar. Hal tersebut dapat dilihat dari berbagai kebijakannya, diantara kebijakan yang lebih signifikan yaitu dalam mengatur perundang-undangan

61 Ading Kusdiana, Sejarah \& Kebudayaan Islam Periode Pertengahan, (Bandung: CV Pustaka Setia, 2013) Hlm: 143 
yang mampu menjadikan tatanan kepemerintahan Kesultanan Turki Utsmaniyah menjadi lebih sistematis dan terkontrol. Salah satu kitab undangundang yang dijadikan pegangan hukum bagi masyarakat Kesultanan Turki Utsmani yaitu Multaqa al-Abhur.

Implikasi dari kebijakan yang dibuat Sultan Sulaiman Al-Qanuni mampu mempengaruhi masyarakat luas, bahkan seluruh wilayah Eropa. Tidak hanya dalam sektor kepemerintahan semata, melainkan sangat perpengaruh dalam bidang politik, bidang pendidikan dan bidang ekonomi serta bidang sosial budaya masyarakat Kesultanan Turki Utsmaniyah.

\section{Daftar Pustaka}

Abu Hasan Ali Affandi, Islam Dan Dunia, (Bandung: Angkasa, 2008)

Al-Azizi Abdul Syukur. Kitab Sejarah Peradaban Islam Menelusuri Jejak-Jejak Peradaban Islam Di Barat dan Timur. Yogyakarta: Saufa. 2014.

Ali Abu'l Hasan. Islam Membangun Peradaban Dunia. Jakarta: PT Dunia Pustaka Jaya. 1988.

Al-Usairy Ahmad. Sejarah Islam. Jakarta: Akbar Media Eka Sarana. 2003.

Amin Samsul Munir. Sejarah Peradaban Islam. Jakarta: Amzah. 2009.

Amstrong Karen. Sejarah Islam “ Perkembangan Islam Sepanjang
Zaman. Bandung: Mizar Pustaka. 2014.

As-Shalabi Ali Muhammad. Bangkit Dan Runtuhnya Khilafah Utsmaniyah. Jakarta: Pustaka AlKautsar. 2011.

Hadi Amirul. Aceh, Sejarah, Budaya, dan Tradisi. Jakarta: Yayasan Pustaka Obor Indonesia. 2010.

Hitti Philip K. History Of Arabs.Jakarta: Serambi Ilmu Semesta. 2005.

Iswanto Yudi. King Sulaiman The Magnificent "Penakluk Hongaria,Serbia Dan Rhodes". Jakarta: Daras. 2015.

Kettani M. Ali. Minoritas Muslim. Jakarta: PT. Raja Grafindo Persada. 2005.

Kuntowijoyo. Metodologi Sejarah. Yogyakarta: Tiara Wacana Yoga. 2005.

Kuntowijoyo. Pengantar Ilmu Sejarah. Yogyakarta: Yayasan Benteng Budaya. 1997.

Rusdin. Statistik Penelitian Sebab Akibat. Bandung: Pustaka Bani Quraisy. 2004.

Kuntowijoyo. Pengantar Ilmu Sejarah. Yogyakarta: Yayasan Bentang Budaya. 1995.

Kusdiana Ading. Sejarah Kebudayaan Islam (Periode Pertengahan). Bandung: CV Pustaka Setia. 2013.

Mansur Suryanegara Ahmad. Api Sejarah 2. Bandung: PT Grafindo Media Pratama. 2012.

Montefiore Simon Sebag. Pahlawan Dalam Sejarah Dunia, Terj: Damaring Tyas Wulandari. Jakarta: Erlangga. 2012.

Mubarok Jaih. Sejarah Peradaban Islam. Bandung: Pustaka Bani Quraisy. 2004. 
Mughni Syafiq A. Sejarah Kebudayaan Islam di Turki. Jakarta: Logos. 1997.

Nurhakim Moh. Jatuhnya Sebuah Tamadun (Menyingkap Sejarah Kegemilangan Dan Kehancuran Imerium Khalifah Islam). Jakarta: Kementrian Agama RI. 2012.

Nizar Samsul. Sejarah Pendidikan Islam "Menelusuri Jejak Sejarah Pendidikan Era Rasulullah Sampai Indonesia”. Jakarta: Kencana. 2007.

Thohir Ajid. Perkembangan Peradaban Di Kawasan Dunia Islam: Melacak Akar akar Sejarah, Sosial, Politik, dan Budaya Umat Islam. Jakarta:Raja Grafindo Persada. 2009.

Yatim Badri. Sejarah Peradaban Islam. Jakarta: Grafindo Persada. 2013.

\section{SKRIPSI:}

Sucipto. Sultan Sulaiman Al-Qanuni 1520-1566 (Kajian Tentang Kebijakan Dan Pengaruh Terhadap Pemerintahan Turki Utsmani). Yogyakarta: Skripsi UIN Sunan Kalijaga. 2014.

\section{INTERNET:}

Ari Sodjaja. Menelusuri Hubungan Antara Aceh Darussalam Dengan Turki Utsmani (Ottoman). https://myrepro.wordpress.com/20 15/10/25/menelusuri-hubunganantara-aceh-darussalam-dengan- turki-utsmani-ottoman-part-1/.

Diunduh Pada Tanggal 22/08/2016 Pukul 20.30 WIB.

http://id.m.wikipedia,org/wiki/Perang_U tsmaniyah-Safawiyah. Di Unduh pada tanggal 30/06/16 Pukul 12.15 WIB.

Amriadi Al masjidy. Sultan Sulaiman Al-Qanuni Dan Turki http://amriadicyber.blogspot.co.id/ 2016/01/sultan-sulaiman-alqanuni-dan-turki.html, diunduh pada tanggal $20 / 05 / 16$ pukul 15.45 WIB.

A'am. Taktik Perang Paling Jenius Kaum Muslim Bagian 2. http://sahabatamrullah.blogspot.co. $\mathrm{id} / 2015 / 07 /$ taktik-perang-palingjenius-kaum-muslim 30.html. Diunduh Pada Tanggal 19/08/2016 Pukul 15.10 WIB.

Peto

Amir:http://bloghistoris.blogspot.c om/2010/12/langkah-langkahpenelitian-sejarah.html?m=1. Di unduh pada tanggal 25/05/2015 pukul 20.15 WIB.

Nurfitri Hadi, Mengenal Sultan Sulaiman al-Qonuni (Suleiman the Magnificent), https://kisahmuslim.com/4774mengenal-sultan-sulaiman-alqonuni-suleiman-themagnificent.html. Diunduh Pada Tanggal 18/08/2016 Pukul 14.35 WIB 